\title{
Czesław Kupisiewicz, Szkice z dziejów dydaktyki. Od starożytności po czasy dzisiejsze, Wydawnictwo Impuls, Kraków 2010, ss. 202
}

Nakładem Wydawnictwa Impuls ukazała się w 2010 r. książka Czesława Kupisiewicza Szkice z dziejów dydaktyki. Od starożytności po czasy dzisiejsze, przedstawiana jako pierwsza próba ujęcia historii dydaktyki jako dyscypliny naukowej. Sam Autor, ukazując czytelnikowi drogowskaz myślowy oraz naukowy swej pracy, napisał iż szkice [...] traktuje jedynie jako punkt wyjścia, pierwsza próbę i wstępny materiat do opracowania historii dydaktyki odpowiadającej współczesnym standardom naukowym. Pozycja, już na „wprowadzeniu”, opatrzona została uwagami terminologicznymi, dotyczącymi tytułu omawianej pozycji. Cz. Kupisiewicz kreśli w nim słownikową definicję „szkicowania”, które w tym przypadku, staje się omówieniem poruszonej problematyki w sposób ogólny, ramowy, bez wnikania w szczegóły. Taki zresztą cel przyświecał Autorowi, jednakże nie należy tego kategorycznie czy jednoznacznie oceniać w pozytywnych, czy negatywnych aspektach. Przyjmuje przy tym formę pierwszych „oględzin”, wstrzemięźliwości oraz „naukowej asekuracji” w interpretacji, zamieszczonej w publikacji, problematyki. Czesław Kupisiewicz skupił się także na sformułowaniu pojęcia „dydaktyka” czy „wychowanie”. Z racji omawianych w niniejszym opracowaniu zagadnień, dotyczących uczenia się i nauczania człowieka, od zarania dziejów po czasy współczesne, brakuje zdefiniowania pojęcia „historia wychowania”, zważywszy na pozycje zakresu tzw. literatury przedmiotu, stanowiące znaczącą część składową bibliografii. Wszak to ta dziedzina nauki relacjonuje dzieje myśli pedagogicznej, dzieje różnych form wychowania i kształcenia, to wreszcie historia instytucji do tego powołanych, czyli to wszystko co w najnowszej książce Czesława Kupisiewcza znaleźć można. To część historii kultury, obejmująca dzieje wychowania i kształcenia szkolnego, edukacji pozaszkolnej. Edukacja, której nierozerwalnymi częściami są wychowanie i kształcenie, rozumiana jest jako źródło informacji o wartościach i technikach charakterystycznych dla danej cywilizacji i epoki ${ }^{1}$. Jako odrębna gałąź wiedzy wyodrębniła się w połowie XIX w. ${ }^{2}$ Początkowo historia wychowania odnosiła się do dziejów myśli pedagogicznej poszczególnych „,filozofów wychowania”. Z czasem, koniec XIX w., w zakres jej zainteresowań włączono sposób wychowania i nauczania realizowanych w ramach organizacji szkolnych, by wreszcie poszerzyć ten zakres o wszelkie formy oddziaływań wychowawczych ${ }^{3}$. Można odnieść wrażenie, że po trosze na siłę, pojęcie „historia wychowania” zostało przeredagowane w hasło „historia dydaktyki” - w ujęciu dyscypliny naukowej.

Książka, składająca się z wprowadzenia, dziesięciu rozdziałów oraz licznych podrozdziałów z zaimplementowaną bibliografią, szkicuje czytelnikowi wkład myślicieli z poszczególnych epok historycznych w rozwój dydaktyki. Niemal każda z omawianych postaci została opatrzona, powielanymi pytaniami: Czy i co wnieśli sofiści do dydaktyki?,

\footnotetext{
1 S. Litak, Historia wychowania, t. I: Od wielkiej rewolucji francuskiej, Kraków 2006, s. 9.

2 S. Kot, Historia wychowania, t. I: Od starożytnej Grecji do połowy XVIII wieku, Warszawa 1996, s. 7.

3 Ibidem.
} 
A co wniosło średniowieczne szkolnictwo do dydaktyki?, Co Erazm z Rotterdamu wniósł do dydaktyki?, Co zatem dydaktyka zawdzięcza Komeńskiemu? A co nowego wnoszą prace KEN do dydaktyki? Sama forma książki jest dość klarowna. Język wydaje się być przystępny i zrozumiały. To pozycja, w której zastosowano układ chronologiczno-problemowy opatrzony określoną myślą historyczną, dydaktyczną i szerzej pedagogiczną. Każdy z rozdziałów posiada podsumowanie, w celu usystematyzowania zdobytych wcześniej informacji. Owe podsumowania są o tyle spójne, iż w każdym z nich dostrzeżemy niemal identyczny szablon, skupiający się na konkretnych zagadnieniach. I tak, znajdziemy w nich bilans celów, treści, zasad, metod i form organizacyjnych, a także środków nauczania, uczenia i uczenia się. Reasumując, to minimalistyczna synteza tego, co dany przedział dziejowy, epoka historyczna (jej przedstawiciele) wniosła do dydaktyki.

Rozpoczynając od sofistów, następnie Arystotelesa i Platona, przytaczając ich poglądy dydaktyczne, Autor wmurowuje kamień węgielny w rozwój myśli o nauczaniu i uczeniu się w okresie starożytności. Prezentując epokę średniowiecza, ukazuje szkolnictwo zdominowane przez Kościół (szkoły klasztorne, katedralne), by w dalszej części zobrazować wychowanie rycerskie, mieszczańskie placówki edukacyjne, na uniwersytetach skończywszy. W okresie odrodzenia podkreśla udział praktycznej działalności w budowaniu podstaw dydaktyki, uwypuklając rolę podręczników jako środków dydaktycznych. Mowa jest także o okresie reformacji i kontrreformacji, w którym to pojawiła się nazwa „dydaktyka”, o doniosłej roli „Wielkiej dydaktyki” Jana Amosa Komeńskiego i postulacie „nauczania wszystkich wszystkiego". Autor podkreśla następnie dydaktyczne osiągnięcia oświecenia, w tym i naszej Komisji Edukacji Narodowej, która wniosła istotny wkład w budowę ojczystej dydaktyki. W ramach - związanego z KEN - Towarzystwa do Ksiąg Elementarnych, opracowano między innymi teorię podręcznika.

Autor publikacji wiek XIX łączy z narodzinami dydaktyki jako dyscypliny naukowej, przywołując twórczą aktywność szwajcarskiego pedagoga Pestalozziego, założenia psychologiczne systemu dydaktycznego Herbarta, czy nowe ujęcia celów, treści i metod pracy dydaktycznej w wersji Marksa i Engelsa. XX wiek staje się wizytówką dalszego rozwoju dydaktyki jako nauki poprzez płynne przejście ze „starej szkoły” do „nowej szkoły”, dzięki nurtowi nowego wychowania. W końcowej części książki, Autor dokonuje próby dydaktycznego bilansu XX wieku. Przywołuje „dydaktykę naukową”, „dydaktykę psychologiczną" wyrosłe z pedagogiki eksperymentalnej oraz psychopedagogiki, a także „dydaktykę elektroniczną”, ściśle powiązaną z wykorzystywaniem komputerów w procesie współczesnej edukacji. Ponadto, ukazuje krajowe i międzynarodowe jednostki organizacyjne, powoływane w ostatnich dekadach XX stulecia w celach reformowania oświaty.

W końcowej części recenzowanej publikacji, dokonując próby dydaktycznego bilansu, Czesław Kupisiewicz wyraża nadzieję, że XXI stulecie przyniesie, zalecane przez ekspertów edukacyjnych, reformy nieustannie potrzebne współczesnemu szkolnictwu.

Opinie o książce Szkice z dziejów dydaktyki. Od starożytności po czasy dzisiejsze są nadzwyczaj jednoznacznie pozytywne: książka wybitna, tak znakomitej książki pedagogicznej nie napisano od wielu lat. Można przyjąć, że celem publikacji było przede wszystkim wypełnienie bądź uzupełnienie „dydaktycznej luki”, w polskiej historiografii oświatowej. Tematyka przedstawiona przez Autora z pewnością zainteresuje historyków 
oświaty, wychowania i nauki, a także samych pedagogów (w tym i dydaktyków), i co do tego faktu nie ma najmniejszej wątpliwości. Recenzowana publikacja stanowi pozycję wyjściową, zachęcającą, a przede wszystkim prowokującą do dalszych dydaktycznych poszukiwań na przestrzeni dziejów. W przypadku rozwinięcia omawianej problematyki, Szkice z dziejów dydaktyki mogą okazać się pozycją niezwykle pomocną, będącą bazą wyjściową dla dalszych poszukiwań i bardziej szczegółowych poczynań badawczych. To wreszcie ciekawa prezentacja rozległości zainteresowań Autora zarówno dla wykładowców, jak i dla studentów, którym nie są obce jego wcześniejsze publikacje.

Konrad Nowak-Kluczyński

\section{Na wygnanie do Tarnopola. Wspomnienia Jana Zamorskiego (1874-1948), oprac. J. Szablicka-Zak, Wyd. Goldruk, b.r. i m. w., SS. 115}

Rola wspomnień i pamiętników dla badaczy przeszłości jest nie do przecenienia. Stanowią one bowiem bogate źródło informacji o minionych czasach, postrzeganych oczami jednostki. Relacje osobiste wymagają jednak osobliwego postępowania badawczego, narażonego na nadmierny subiektywizm, ale czyż każda proponowana wersja historii nie jest także wersją autorską? Są także owe wspomnienia często jedynym źródłem dla odtworzenia informacji, których próżno byłoby szukać np. w archiwach (np. kwestie dotyczące świadomości, mentalności etc.). W tym kontekście każda inicjatywa wydania i edycji czyichś wspomnień jest cenna.

Taką właśnie pozostaje aktywność Jolanty Szablickiej-Żak, wrocławskiej badaczki historii wychowania, która pokusiła się o wydanie zapisków Jana Zamorskiego (18741948), absolwenta Uniwersytetu Jagiellońskiego, profesora c.k. Wyższej Szkoły Realnej w Tarnopolu, działacza Towarzystwa Szkoły Ludowej i Towarzystwa Gimnastycznego „Sokół”, animatora czasopiśmiennictwa kresowego i, wreszcie, posła do parlamentu austriackiego, Sejmu Krajowego galicyjskiego i Sejmu w odrodzonej Rzeczypospolitej. Już sam ten wykaz funkcji przezeń sprawowanych sugeruje, iż Zamorski był postacią niezwykle interesującą, a jego osobiste cechy spowodowały, że także osobą niezwykle barwną i nawet $\mathrm{z}$ racji na poglądy - kontrowersyjną.

Książka, z racji na swój gatunek ma prostą konstrukcję. Zaczyna się od „Wstępu” i rozdziału, który pokrótce przedstawia sylwetkę Jana Zamorskiego i kreśli szkic Tarnopola. Miasto nie jest przypadkowe, gdyż właśnie tam umiejscowione są wydarzenia opisane przez Zamorskiego. W Tarnopolu bowiem zaczynał on swoją karierę jako nauczyciel. Treść zasadniczą pracy stanowią właśnie jego zapiski. Całość zamyka spis bibliografii, obejmujący nie tylko źródła, opracowania, ale także spis prac J. Zamorskiego.

Prezentowana książka jest ważna szczególnie dla środowiska historyków wychowania. Po pierwsze dlatego, że Zamorski jako praktykujący nauczyciel miał świadomość, że jego zapiski mają walory pedagogiczne. Problematyka związana z życiem szkoły jest bo- 